University of Louisville

ThinkIR: The University of Louisville's Institutional Repository

\title{
A survey of the Cuban government's prospects of attracting foreign direct investment.
}

Philip Moore

Follow this and additional works at: https://ir.library.louisville.edu/honors

Part of the International Economics Commons, and the Political Science Commons

\section{Recommended Citation}

Moore, Philip, "A survey of the Cuban government's prospects of attracting foreign direct investment." (2016). College of Arts \& Sciences Senior Honors Theses. Paper 102.

http://doi.org/10.18297/honors/102

This Senior Honors Thesis is brought to you for free and open access by the College of Arts \& Sciences at ThinkIR: The University of Louisville's Institutional Repository. It has been accepted for inclusion in College of Arts \& Sciences Senior Honors Theses by an authorized administrator of ThinkIR: The University of Louisville's Institutional Repository. This title appears here courtesy of the author, who has retained all other copyrights. For more information, please contact thinkir@louisville.edu. 


\title{
A Survey of the Cuban Government's Prospects of
} Attracting Foreign Direct Investment

\author{
By Philip Moore
}

Submitted in partial fulfillment of the requirements for Graduation summa cum laude and for Graduation with Honors from the Department of Political Science

University of Louisville May 2016 


\section{$\underline{\text { Preface }}$}

This work attempts to capture the critical issues plaguing Cuba's continual economic dependency and suggests potential avenues for greater foreign direct investment. For the past year, I have been working to develop a framework to assess the current state of the Cuban economy in relation to foreign investment. However, I must acknowledge a few key limitations of my research. First, Cuba's economic data is scarce and has often been criticized as unreliable or contradictory. Second, as Cuba operates a dual currency system, the actual cost and value of goods is difficult to calculate since the currencies trade at an artificial and fluctuating exchange rate. Third, bias of official reporting of Cuban economic studies and statistics is rampant and difficult to gauge: the Castro government has a long history of internal disagreement regarding the interpretation of official data. This has resulted over the years in extremely divergent and even contradictory official economic analyses.

In light of these limitations, I will utilize Cuba's National Office of Information and Statistics' annual reports as they provide the most informative reporting of economic data, albeit vague and difficult to interpret at times. In addition, I will draw upon the economic reports published by the Center for the Study of the Cuban Economy, an influential policy center in Havana. During my research stint in Havana I had the opportunity to spend a week at the Center's library and immerse myself in the current writings on the domestic economy, and I will include firsthand accounts of this experience. Through a mix of first and secondhand accounts, I will provide an overview of the history of Cuban economic dependency, its implications, an assessment of the current reforms and the potential for future foreign investment in Cuba.

I wish to express my sincere appreciation to the Center for the Study of Cuban Economy's Director Dr. Omar Everleny for his hospitality and cordiality during my visit. I would also like to thank Dr. Felix Valdes who introduced me to Dr. Omar Everleny, 
coordinated my independent study of the Cuban economy in Havana, and offered me ample resources for my research project. I would like to recognize Dr. Julie Bunck for her assistance as the faculty advisor for this project. Dr. Bunck's previous works on Fidel Castro and Cuba inspired my special interest in the Cuban economy, leading me to a research proposal that was the foundation of this thesis. In a similar vein, my time researching in Cuba would not have been possible without the financial support of various entities and people. I am grateful for Dr. Patricia Condon's enthusiasm and support of my research and the generous funding awarded to me by the University of Louisville Honors Program through the Irvin F. and Alice S. Etscorn International Summer Research Award. I thank David and Betty Jones for their consistent promotion of a global education through generous funding initiatives. I would like to acknowledge Dr. Gary Gregg and the McConnell Center for their continued investments in my education. Finally, I would like to express my gratitude to Glyptus Grider-Jones, Elizabeth Liebschutz, Dr. Tricia Gray, and Dr. John Gibson. 
Table of Contents

I. Introduction 5-6

II. Review of Applicable Theory 6-19

III. Historical Overview of Economic Dependency 19-31

IV. Modern-day Reforms, Assessment of Revolutionary Goals, and the Current State of the Economy $31-33$

V. Future Prospects 34-39

VI. Conclusion 39-41 


\section{Introduction}

After fifty years of governance within a closed economic system, Cuba has initiated a move to integrate into the world market. With its current economy nearing complete bankruptcy, however, lingering international distrust, as a result of its complete nationalization without compensation of foreign and domestic businesses in the 1960s, and suspicion about the accuracy of the government's current official economic statistics, many multinational businesses remain wary of investing significantly in Cuba. Moreover, the U.S. embargo against Cuba places major restrictions on the import and export of goods and limits most Americans from traveling to Cuba unless they have a legal purpose for doing so.

While many adverse conditions still exist for foreign investment in Cuba, the island's government has implemented a new foreign investment law that would greatly benefit multinational corporations and attempts to foster an environment of support for public-private partnerships. ${ }^{1}$ Since President Raul Castro has stated that he will not remain at the head of state for long, and Cuban leaders assume that the embargo will soon be lifted, government officials are scrambling to transition the economy in preparation for these events. In reaction to these realities, economists in Cuba and abroad have set out to create a framework for assessing Cuba's economic future and to develop meaningful comparisons to other transitional economies. The goal of these studies is to find an economic path that is both sustainable and effective.

To begin, this paper will carefully assess the prospects of foreign investment in Cuba. Next, the paper presents a review of the relevant literature in the field of developmental and Caribbean economics. Finally, the third section will present a historical overview of both Cuba's long-enduring economic dependency and the more recent reforms of Raul Castro and

\footnotetext{
${ }^{1}$ Law No. 118 Foreign Investment Act. National People's Power Assembly. Mar. 29, 2014.
} 
an analysis of the current economy in relation to the goals of the revolution. From this intensive historical and present-day study of the economy, the future prospects of the economy will be considered leading to in-depth examination of the advantages and disadvantages of foreign investment. A brief conclusion will summate this paper and close with a personal anecdote emblematic of Cuba's future.

\section{Relevant Literature}

\section{The Plantation Economy}

Lloyd Best and Kari Levitt's Essays on the Theory of Plantation Economy develops a new conceptualization of the Caribbean economy. Through of a series of complex case studies, the authors offer an ideological alternative to neo-liberalization and promote a different understanding of the Caribbean region. Their perspective of the plantation economy argues that the economies of Caribbean islands are fairly homogenous - detailing similarities among Cuba, Trinidad and Tobago, and the Dominican Republican - and lays out a system of reasoning for why the region should be viewed differently than the rest of the world. ${ }^{2}$ The theory of the plantation economy originates from the historically agricultural-based system reliant on slave labor, which was more lucrative for the investing state, Spain, than the domestic workers. The centuries of exploitation points to a systemic phenomenon that favors an imbalance of trade, creating an economic dependency model. The theory of plantation economy's structural approach attempts to explain why the Caribbean islands "undergo alternating cycles of 'boom' and 'bust', why periods of boom are not self-sustaining, and why adjustment during the bust does not free the economy from dependence."3

\footnotetext{
${ }^{2}$ Best, Lloyd, and Kari Levitt. Essays on the Theory of Plantation Economy: A Historical and Institutional Approach to Caribbean Economic Development. Kingston, Jamaica: U of West Indies, 2009.

${ }^{3}$ Given, Norman. "The Plantation Economy in the Age of Globalization." Rpt. in Essays on the Theory of Plantation Economy. U of the West Indies, 2009.
} 
The plantation economy, in short, represents the foreign-owned and export-oriented sector, and key examples are agriculture, mining, and tourism. The link to both slavery and exploitation by the foreign sovereign can easily be found in all of these sectors, and until a Caribbean economy diminishes these areas and replaces them with residentiary sectors like manufacturing, foreign dependency will sharply characterize the economic fate of the island. In Best and Levitt's interpretation, the theory of plantation economy does not embrace a fatalistic approach; instead it presents a method of re-conceptualizing the Caribbean structural approach to economics in order to explain the historical difficulties that these economically homogenous countries have faced as they attempt to modernize and become more independent and self-sufficient. Although the essays were written more than 50 years ago, the same issues are still present in Cuba. It has not advanced its residentiary sector, and it maintains a strong reliance on its plantation economy as the basis of an export-oriented, foreign-dependent economy. Past examples of the adverse effects of this overreliance are plentiful.

\section{Import-Substitution Industrialization}

Related to the theory of plantation economy but more expansive in terms of regional and global inclusion, import-substitution industrialization is a structural approach to economics that attempts to explain what policies account for the difference between developed and developing nations. In other words, the import-substitution model addresses the systemic issues that lead to mass poverty in low-income nations. ${ }^{4}$ The long-term cause is generally linked to the dominance of agriculture or mining in an exploited country as opposed

\footnotetext{
${ }^{4}$ Bruton, Henry J.. "A Reconsideration of Import Substitution". Journal of Economic Literature 36.2 (1998): 904.
} 
to the diversified, service-based economy of an industrialized country. ${ }^{5}$ Linus Thomas'

review of Raul Prebisch's economic development theory reinforces this root cause:

A disproportionate amount of the benefits of technological progress seemed to accrue to the Center [developed countries] leaving the periphery [underdeveloped countries] with nothing but labor-intensive activities. Since labor is generally abundant in these economies, the rewards for technological improvements are very low in both production of the traditional goods and the emerging manufacturing industries. ${ }^{6}$

Since the global economic paradigm concentrates technological and capital advancements in industrialized countries, low-income countries struggle to grow - only attracting industries that need inexpensive labor - and ultimately lack highly profitable manufacturing and service-based firms. ${ }^{7}$

The theory suggests that these countries should invest in replacing imports by manufacturing them domestically and setting up trade barriers to protect these industries against the better established companies in high-income countries. After World War II, many countries of Latin America actively implemented state-sponsored policies of importsubstitution industrialization as they sought to escape the market volatility they suffered during the first half of the twentieth century and to avoid the devastating impact of another Great Depression. Economic analyses, including critiques and reconsiderations of these policies have proliferated over the last several decades. ${ }^{8}$

Common aspects of these essays support a few weaknesses and strengths of importsubstitution industrialization. In most cases, gross domestic product increased, but the growth

\footnotetext{
5 Ibid. 904.

${ }^{6}$ Thomas, Linus J.. "Neoclassical Development Theory and the Prebisch Doctrine: A Synthesis". The American Economist 38.1 (1994): 77.

7 Bruton, Henry J.. “A Reconsideration of Import Substitution”. Journal of Economic Literature 36.2 (1998): 904.

${ }^{8}$ Baer, Werner. "Import Substitution and Industrialization in Latin America: Experiences and Interpretations". Latin American Research Review 7.1 (1972): 95-122. Bruton, Henry J.. "A Reconsideration of Import Substitution". Journal of Economic Literature 36.2 (1998): 903-936. Thomas, Linus J.. "Neoclassical Development Theory and the Prebisch Doctrine: A Synthesis". The American Economist 38.1 (1994): 75-81. Hirschman, Albert O. 1968. The Political Economy of Import-Substituting Industrialization in Latin America. Quarterly Journal of Economics 82, 1: 1-32. Krueger, Anne O. "Trade Policy as an Input to Development." The American Economic Review, Vol. 70, No. 2, (May 1980), pp. 288-292.
} 
did not keep up with the accumulated foreign debt that was required to carry out these

sweeping reforms and take on the various capital projects needed to make goods

domestically. The import of needed capital goods alone often outweighed the profits made

from the product. In addition, the quality of domestically made goods were often well below international standards while their prices were well above. The attempt by some countries to

make automobiles demonstrates well this set of problems:

A study by Baranson of automobile industries in developing countries (which includes information on Argentina, Brazil, and Mexico)... finds that among the main deficiencies are '... underdeveloped supplier capacities, inadequate quality control systems, and a dearth of qualified technicians and managers...' Thus, Baranson found that many ' ... basic materials that are considered standard stock in open economies often must be procured locally or specially ordered in small batches at considerably higher cost or at inferior quality... Lack of uniformity in raw materials and semifinished goods such as castings and forgings creates special problems in milling and machining to required specifications. In high-volume production, precision and uniformity are built into automated equipment. Developing countries with limited markets are much more dependent upon the very machine labor skills in which they are deficient.' Also, considering the many parts which go into an automobile, Baranson found that outside plant procurement averages about 60 per cent by value in advanced economies, while in countries like Mexico and Brazil this factor amounts to only 40 per cent. Such a condition further reduces the possibility of economies of large scale production. As a result, Baranson found that factory costs in Argentina, Brazil, and Mexico were about 60 per cent to 150 per cent higher than in the United States. ${ }^{9}$

This evaluation of a specific sector yields critical data needed to surmise the usefulness of import-substitution industrialization. First, the automobile industry serves as a failed experiment of import-substitution, and from a cost perspective, it highlights the difficulty of competing with highly advanced countries and the importance of economies of scale. Closing the domestic economy by adding tariffs eliminates foreign competition, thereby, creating inefficiencies in the market. Moreover, as a country creates tariffs and prevents imports from flowing into the state, it simultaneously limits its economic potential for exports: "A country

\footnotetext{
${ }^{9}$ Baer, Werner. "Import Substitution and Industrialization in Latin America: Experiences and Interpretations". Latin American Research Review 7.1 (1972): 104-105. Baranson, Jack. Automotive Industries in Developing Countries. (Baltimore 1969). 25-26.
} 
that is closed for imports is closed for exports." ${ }^{10}$ Although a negative for the global economy, protectionism in certain cases helps a developing country scale its production of a good in order to compete globally eventually.

Another takeaway from the Latin American experience involves the importance of local raw materials and resources. Countries without the necessary raw materials for production must make trade deals to acquire them. This reveals several key drawbacks. First, it makes the finished product susceptible to the volatile commodity prices of the intermediate goods. Second, the country requires proper supply-chain management in order to avoid major shortages and surpluses of raw materials. Third, the state needs scale to negotiate a better price for the raw material, or the cost will be too great to compete with advanced countries that receive or extract the materials for a much cheaper price. These lessons must be heeded for an import-substitution model to function properly. The Latin American example of import-substitution as a whole "was indiscriminate, that is, there were not attempts to concentrate on industrial sectors which might have had a potential comparative advantage." 11 Coupled with the economic shortages was widespread official corruption that resulted in the waste of a staggering of money and resources. General widespread state mismanagement generally added to the failure.

\section{Comparative Advantage - Export Oriented Industrialization}

The basis of comparative advantage relies on the principle that goods and services have factor intensities and are either capital-intensive or labor-intensive, and as such, a

\footnotetext{
${ }^{10}$ Feinberg, Richard, and Ted Piccone. Cuba's Economic Change in Comparative Perspective. Latin America Initiative Foreign Policy at Brookings, 2014: 73.

${ }^{11}$ Baer, Werner. "Import Substitution and Industrialization in Latin America: Experiences and Interpretations". Latin American Research Review 7.1 (1972): 98.
} 
particular location offers optimal production. ${ }^{12}$ As previously discussed, labor-intensive goods will generally become associated with poorer countries, and capital intensive-goods will gravitate toward advanced economies where capital is relatively cheaper. The theory of comparative advantage supports this simple distribution of production through the concept of specialization. The economics of trade strongly contradicts a state's decision to leave the world market; comparative advantage, from a macro lens, shows that world production increases when states specialize. While states vary in the degree to which they become better off from specialization, every state's economic production should expand as a result. Thus, an attempt by a state to become completely self-sustaining implies a contraction of its economic potential. Limiting integration with the global economy might lead to significant undervaluation of a state's currency, and the state would be at a disadvantage if it needed foreign assistance or loans for investment projects. Additionally, the state would need to have ample raw materials and natural resources or an agreement to receive them. The scarcity of natural resources, along with random geographic allocation, presents a significant obstacle to a state that desires to build a self-sustaining economy.

The developing countries that serve as representatives of successful transitions to a marked level of self-sufficiency tend to be the Southeast Asian countries. ${ }^{13}$ Protective legal barriers combined with foreign investment incentives, a commitment to export promotion, and disciplined, structured management, provided the right balance for the economic growth

\footnotetext{
12 Widodo, Tri. "Dynamic Comparative Advantages in the ASEAN+3". Journal of Economic Integration 24.3 (2009): 506.

13 Widodo, Tri. "Dynamic Comparative Advantages in the ASEAN+3". Journal of Economic Integration 24.3 (2009): 505-529. Le, Quoc-Phuong. "Evaluating Vietnam's Changing Comparative Advantage Patterns". ASEAN Economic Bulletin 27.2 (2010): 221-230. Bresnan, John. From Dominoes to Dynamos: The Transformation of Southeast Asia. New York: Council on Foreign Relations Press, 1994. Frey, Marc, Ronald W. Pruessen, and Tai Yong. Tan. The Transformation of Southeast Asia: International Perspectives on Decolonization. Armonk, N.Y.: M.E. Sharpe, 2003. Jomo K. S. Southeast Asia's Industrialization: Industrial Policy, Capabilities, and Sustainability. Houndmills, Basingstoke, Hampshire: Palgrave, 2001. Machikita, Tomohiro, and Yasushi Ueki. "Measuring and Explaining Innovative Capability: Evidence from Southeast Asia." Asian Economic Policy Review 10.1 (2015): 152-173
} 
that these Southeast Asian countries sustained during the late-1900s. Through careful and thoughtful planning, a diversified economy that invested in sectors associated with strong comparative advantages, and scrupulous debt accumulation, these countries became advanced industrialized nations and serve as models for other developing countries.

Economists have carefully studied the economic transitions of Southeast Asian countries and have found Vietnam to be a potential model of reform for Cuba. ${ }^{14}$ Kanako Yamaoka makes the comparison to suggest that a transition to a market-based economy is possible in an autocratic regime. ${ }^{15}$ In No More Free Lunch: Reflections on the Cuban Economic Reform Process and Challenges for Transformation, Pavel Vidal, Omar Everleny and Claes Brundenius and Doanh Le Dang have all contributed articles on comparisons of Cuba to Vietnam. Pavel Vidal emphasizes the monetary and financial similarities to Vietnam, and Omar Everleny connects the foreign direct investment prospects to Vietnam's successful transition. Meanwhile Claes Brundenius and Doanh Le Dang focus on entrepreneurship and small enterprises in relation to Vietnam. Pavel Vidal and Omar Everleny are prolific economic-policy experts and scholars at the influential Center for the Study of the Cuban Economy, and their conscious decision to model Cuba's transition after Vietnam suggests that future policy decisions will consider Vietnam's economic past. A critique of the comparison might argue that the economies are not that similar; for example, "In 1990 Vietnam's was greater than 40\%. By 2012 Vietnam's [share had fallen] to $19.3 \%$. By contrast, Cuba's share of GDP in 2012 was $3.8 \% .{ }^{16}$ In this sense, the distribution of GDP and

\footnotetext{
${ }^{14}$ Brundenius, Claes, and Pérez R. Torres. No More Free Lunch: Reflections on the Cuban Economic Reform Process and Challenges for Transformation. 2013: 63-82, 129-151, \& 173-192.

${ }^{15}$ Yamaoka, Kanako. The Feasibility of Cuban Market Economy: A Comparison with Vietnam. Issue brief no. 189. Chiba-Shi Chia Japan: Institute of Developing Economies. Yamaoka, Kanako. Comparison of Two Remaining Socialist Countries-Cuba and Vietnam: Possibility of Economic Reform in a Socialist Society and Its Possible Impact. Issue brief no. 07-15. Cambridge, MA: Program on U.S.-Japan Relations, Harvard University, 2007.

${ }^{16}$ Betancourt, Roger. "Cuba 2014: A Different Perspective on Cuba's "Structural” Reforms. Association for the Study of the Cuban Economy 24 (2014): 96.
} 
agricultural dependence greatly differs between the two countries, yet that distinction does not merit ignoring Vietnam as a model - only it suggests a reasonable framing for how to view Cuba in the context of the Vietnamese transformation.

\section{Foreign Direct Investment - Trust}

The theory of plantation economy, import-substitution industrialization and exportorientated industrialization all address the policies that a central government should implement in order to promote economic growth. A tool that these policies use is foreign direct investment. Foreign direct investment is "the creation or expansion of firms that operate across borders." ${ }^{17}$ This expansion of firms does not always leave a net benefit on the economy, and therefore, the state should exercise a modest degree of discretion in shaping a trade policy to ward off net negative foreign investments. ${ }^{18}$ Economists disagree on the premise behind foreign direct investment. One school of thought assumes that "highly competitive, profit-maximizing firms [seek] to minimize their costs of production."19 Economists who argue against that assumption generally view foreign direct investment as a way firms “(1) capture monopoly profits abroad... and/or (2) maintain market positions abroad as alternative suppliers in the local market itself and in other foreign countries to become more competitive." ${ }^{20}$ Understanding the underlying reason behind a firm's decision gives a host country a better chance of attracting foreign direct investment:

Direct investment should be thought of primarily as an issue in industrial organization, not in capital flow. That is, analysis should focus more on the reasons

\footnotetext{
${ }^{17}$ Froot, Kenneth. Foreign Direct Investment. Chicago: U of Chicago, 1993: 21.

${ }^{18}$ Feinberg, Richard E. The New Cuban Economy: What Roles for Foreign Investment? Washington, DC: Brookings Institution, 2012: 3.

${ }^{19}$ Ray, Edward John. "Foreign Direct Investment in Manufacturing”. Journal of Political Economy 85.2 (1977): 284.

${ }^{20}$ Ibid 284.
} 
why multinational firms exist and have advantages than on the international flows of money per se. ${ }^{21}$

Although trade and foreign investments are generally viewed by the imports and exports of a country or its trade balance or imbalance, the necessary component - in terms of analysis - is the industrial organization. Control over the manufacturing and operations (or the contracting) of a domestic company poses a difficult choice for firms; however, according to Kenneth Froot, control over the investment creates a more efficient operation. ${ }^{22}$ Cuba's jointventures, therefore, might lead to small inefficiencies, but the domestic profit will generally offset the loss of production. Economic gains of foreign-direct investment for a host country include income tax and indirect benefits to the private sector through spill-overs of productivity. ${ }^{23}$ The likelihood of foreign direct investment increases in industries that consist of corporations with strong financial moats: "Where products are differentiated, reputation is vital, and technology is firm specific and constantly improving." ${ }^{24}$ While other companies and industries might be targets of foreign investment, the majority of firms will have common links to the previous industry description. A concern of host countries about foreign direct investment considers how well domestic companies can compete with foreign subsidiaries. Drawing upon examples from Japan, China and Korea, scholars have shown that these countries had rigid investment laws that helped protect their local businesses, giving them time to increase production. ${ }^{25}$ As for the difficulty of attracting investment, firms require a concrete reason why they should make foreign investments in a country as opposed to simply trading with that country:

Direct invest investment will be chosen instead of, or adjunct to, trade only to the extent that the location offers a substantial advantage to the company. This advantage may result from the unusual comparative advantage as reflected in lower production

\footnotetext{
${ }^{21}$ Froot, Kenneth. Foreign Direct Investment. Chicago: U of Chicago, 1993: 29.

22 Ibid 1.

${ }^{23}$ Caves, Richard E.. "Multinational Firms, Competition, and Productivity in Host-country Markets".Economica 41.162 (1974): 177.

${ }^{24}$ Froot, Kenneth. Foreign Direct Investment. Chicago: U of Chicago, 1993: 40.

${ }^{25}$ Fukuyama, Francis. Trust: The Social Virtues and the Creation of Prosperity. New York: Free, 1995: 339.
} 
costs. Barriers to imports or other host-country policy inducements also play a role in determining the most advantageous location for production. ${ }^{26}$

In this context, Cuba has strengths for attracting foreign direct investment in three different categories; 1) its natural resources including mining, potential oil reserves, and its tropical environment; 2) its highly educated population helps differentiate Cuba's human capital especially at its lower relative wages; and 3) Cuba's market is fairly closed to external agents, making corporations more apt to attempt to penetrate the market. ${ }^{27}$

Cuba faces extra obstacles as it attempts to seek out foreign direct investment. Over the past fifty years, Cuba has acted in bad faith in a variety of ways including the expropriation of U.S. businesses and the false reporting of its economic data. ${ }^{28}$ As such, trust becomes relevant to the discussion of a firm's willingness to invest in Cuba. Fukuyama defines trust as "the expectation that arises within a community of regular, honest, and cooperative behavior, based on commonly shared norms, on the part of other members of the community." 29

In relation to trust, Fukuyama prescribes social capital as "a capability that arises from the prevalence of trust in a society. ${ }^{30}$ States or actors evaluate the social capital of others through cultural tendencies like historical precedent. Thus, a historical economic review becomes critical to the evaluation of a country's ability to attract foreign direct investment. Once trust has been lost in a society, it is very difficult to regain:

Social capital is like a ratchet that is more easily turned in one direction than another; it can be dissipated by the actions of governments much more readily than those governments can build it up again. ${ }^{31}$

\footnotetext{
${ }^{26}$ Froot, Kenneth. Foreign Direct Investment. Chicago: U of Chicago, 1993: 40-41.

${ }^{27}$ Feinberg, Richard E. The New Cuban Economy: What Roles for Foreign Investment? Washington, DC: Brookings Institution, 2012: 15.

28 Ibid 19.

${ }^{29}$ Fukuyama, Francis. Trust: The Social Virtues and the Creation of Prosperity. New York: Free, 1995: 26.

30 Ibid 26.

31 lbid 362.
} 
The lack of social capital makes an investment in Cuba less appealing, and as such, a higher risk premium must be applied. Since Cuba's growth potential is high and most of its land remains untapped, the effect of minimal social capital is rather limited. However, if the Cuban government continues to expropriate land, cancel contracts, and make foreign investing difficult, the trust factor's relative importance will rise exponentially. Even if a democratic transition takes place, simultaneous capitalistic reforms must also occur in order to maintain a democratic order and reestablish trust. ${ }^{32}$ Fukuyama prescribes these capitalistic reforms as necessary because they help create "firms, entrepreneurs, markets and competition" through the development of capitalistic institutions, and he points to the difficulties that the Eastern European countries faced as they attempted to transition into democracies after the fall of Soviet Union. ${ }^{33}$ Cuba diverges from these historical examples in this regard, however. ${ }^{34}$

Fukuyama's overall theory of trust does provide a lens through which to see Cuba: "Low-trust societies, by contrast, must fence in and isolate their workers with a series of bureaucratic rules." 35 This principle directly reflects the treatment of workers for roughly 20 companies starting in the 1980 s and continuing up until Raul came to power. Fukuyama, a staunch proponent of capitalism who proclaimed the "unabashed victory of economic and political liberalism," suggests that a low-trust society needs "a more intrusive, rule-making government to regulate social relations." ${ }^{36}$ In that sense, a state-controlled economy has its advantages domestically and internationally when it has a history of actions that jeopardizes

\footnotetext{
32 Ibid 356.

${ }^{33}$ Ibid 356.

${ }^{34}$ Ritter, Archibald R., Ted Henken. Entrepreneurial Cuba: The Changing Policy Landscape. First Forum Press, $11 / 2014$.

${ }^{35}$ Fukuyama, Francis. Trust: The Social Virtues and the Creation of Prosperity. New York: Free, 1995: 28.

${ }^{36}$ Fukuyama, Francis. “The End of History?” The National Interest 16 (1989): 3.

Fukuyama, Francis. Trust: The Social Virtues and the Creation of Prosperity. New York: Free, 1995: 361.
} 
its social capital. The disadvantages of a command economy with low social capital are that most of its companies will be inefficient and corruption will rise. ${ }^{37}$

Political risk also plays a critical role in the pursuit of foreign direct investment since "The absence of supranational courts limits legal remedies and where an investor's foreign nationality limits redress through domestic political institutions." ${ }^{38}$ In Cuba, the government controls both the courts and the institutions, and the centralization of power allows most of the decisions to be made a higher level, creating significant political risk. Article 60 of the 2014 Foreign Investment Act explains the process of settling disputes, and it essentially vests all the power into the Economic Division of the particular Provincial People's Court. ${ }^{39}$ An illustration of the significance of this section involves the right to terminate or renew a contract. If the government decides that a foreign corporation has violated a section of the foreign investment contract, the contract can be terminated, and the only legal remedy the corporation has is to appeal the termination to the provincial court, which is an extension of the government. Thus, the final decision will not be made by a neutral, third party.

Political risk also includes the historical acts of the government. The determination of the sustained impact of past acts of expropriation and default play a key role in calculating the political risk associated with investments in Cuba. While a company that has had its assets expropriated would most likely avoid future investment, other companies that were not directly affected by past acts of expropriation would still consider investment as long as the reward was worth the incentive. Cuba offers a completely new market for investors, and as such, the island compels foreign companies to invest in its potential. The financial implications of the current United States sponsored embargo discourages firms from

\footnotetext{
${ }^{37}$ Fukuyama, Francis. Trust: The Social Virtues and the Creation of Prosperity. New York: Free, 1995: 358.

${ }^{38}$ Tomz, Michael, and Mark L. J. Wright. "Sovereign Theft: Theory and Evidence about Sovereign Default and Expropriation." 2008: 69.

39 Law No. 118 Foreign Investment Act. National People's Power Assembly. Mar. 29, 2014.
} 
investing in Cuba; however, once the government lifts it, companies will be more likely to try and penetrate the Cuban market. The next political transition will have a tremendous effect on the risk associated with investment. When Raul Castro steps down, his successor will create a new perspective from which to judge the trustworthiness of investment. If risk averse, the leader will be motivated to expropriate foreign assets in bad times; however, if the next president does not fear risk, he or she might be willing to centralize foreign investment in good times in order to fortify power and control. ${ }^{40}$ These considerations should be carefully evaluated by companies looking to invest, and as such, the successor should work to establish a reputation of trust and ethical behavior.

This literature review suggests a few economic principles that will guide the analysis of Cuba's foreign investment prospects. First, Cuba must build its residentiary sector, but the focus should be on only areas of comparative advantage. Protective laws and barriers are required to stabilize economic transition and prevent a resurgence of economic dependence. Strategic planning by the state sector needs to be implemented in order to create incentives for foreign investment and growth. Diversification is necessary; however, the diversity of exports should be limited to the fields of comparative advantage. Cuba must build its social capital. It must select an economic model that promotes the market and allows firms and entrepreneurs to thrive.

Moreover, after making its selection, Cuba must maintain its course. Cuba has a long history of reversing its trajectory, often relying more on idealism and less on a sound plan. This next economic policy must be grounded in reality, and the government must show how the revenue totals more than cost. To the outside world, Cuba must project a new self: a country that cares about its international image. It must make timely payments on its debt,

\footnotetext{
${ }^{40}$ Tomz, Michael, and Mark L. J. Wright. "Sovereign Theft: Theory and Evidence about Sovereign Default and Expropriation." 2008: 106.
} 
eliminate its dual currency system. and join the modern world. Cuba must embrace its highly educated population and attract investment that focuses on work that needs highly educated labor. In addition, Cuba must develop methods to keep this population from leaving; without its sharpest minds, Cuba will be at a major disadvantage as it reintegrates into the world economy. While this study has primarily addresses the external sector, the social capital must also be improved domestically in order to advance the quality of life of citizens. One of the best options for improving the standard of living is by promoting entrepreneurship and removing the barriers to entry.

Cuba must reexamine the progress it has made on its revolutionary goals. Through its platform of growth with equity, Cuba has expanded the literacy rate, improved public schooling, and advanced the healthcare sector. The next economy policy must account for these gains, and economic growth should only be pursued when it does not force the government to sacrifice these achievements or the equity that was created throughout the second half of the twentieth century.

\section{Historical Overview of Cuban Economic Dependency}

For the past 500 years Cuba has struggled to be self-sufficient and independent, and it has a complex history of economic dependency and monoculture exportation. During the early history of Cuba after its discovery by Spain, the small native population was nearly exterminated, and thus, the Spaniards created a two- class system or plantation system, which consisted of a wealthy land-owing elite and a slave class. Since the native population had almost totally perished as a result of disease and conquest, the Spanish had to import a huge population of African slaves. Present-day Cuban culture and ethnicity can be traced back to the sixteenth century with the import of African slaves. Through its global merchant fleet, 
Spain exported Cuban sugar all over the world, and by 1856 Cuban sugar dominated the world market accounting for 25 percent of global sugar. ${ }^{41}$ This stratified system of Spanish mercantilism essentially remained in place until the end of the nineteenth century. It weakened slightly in 1884, however, when the world price of sugar dropped significantly, forcing many sugar mills to declare bankruptcy. ${ }^{42}$ Seeing an investment opportunity, U.S. firms poured millions of dollars into the Cuba's sugar industry, cementing Cuba's relations with the United States. Finally, after nearly three decades of resistance against Spanish ownership, the Cubans gained their independence in 1898 with U.S. assistance. While Cuba legally gained full independence, it nevertheless remained heavily tied to the U.S. economy and enjoyed little authentic economic independence.

In the late 1950s Fidel Castro led a revolt against the American-supported military dictatorship of Fulgencio Batista. Revolution promised true independence and the end of Cuban reliance on the United States. Following the revolution, the Cuban economy followed cyclical transitions as the command economy made various attempts to stimulate growth and maintain equity. Carmelo Mesa-Lago and Jorge Perez-Lopez breakdown the period from 1959 to 2012 into eight distinct cycles:

1959-1966: Although difficult to classify, this was mostly an idealist cycle, with some facets of pragmatism particularly in 1964-1966; this period is divided into three subcycles: market erosion, introduction of orthodox Soviet central planning, and debate over socialist models.

1966-1970: Fidel's adoption and radicalization of the Guevarist model, a strong idealist cycle.

1971-1985: Total collapse of the Cuban economy and the introduction of the Soviet timid (pre-Gorbachev) economic reform model, the first well-identified pragmatist cycle.

1986-1990: The so-called Rectification Process, the third idealist cycle.

\footnotetext{
${ }^{41}$ Leogrande, William M., and Julie M. Thomas. "Cuba's Quest for Economic Independence”.Journal of Latin American Studies 34.2 (2002): 325.

Thomas, Hugh. Cuba: The Pursuit of Freedom (New York, 1971), 126.

42 Leogrande, William M., and Julie M. Thomas. "Cuba's Quest for Economic Independence".Journal of Latin

American Studies 34.2 (2002): 325.
} 
1991-1996: Crisis and market-oriented reforms, the second and strongest pragmatist cycle up to this point, under the "Special Period in Time of Peace."

1997-2003: Slowdown and halt of the reform, a cycle of policy stagnation.

2003-2006: Reversal of reforms, the fourth idealist cycle, although weaker than previous idealist cycles.

2007-present: Raúl Castro's structural reforms, the third and strongest pragmatist cycle of the revolution. ${ }^{43}$

This 50-year period of abrupt shifts in policy direction and subsequent reforms underlie a critical set of contradictions with which the Cuban leadership has continually struggled. The government has failed to find the right balance of economic reforms to bolster the economy, and when changes have actually begun to work, the subsequent diminishing of ideological fervor throughout the country have consistently prompted the government to implement often sweeping policy reverses, eliminating the gains from the previous cycle. A more detailed review illuminates this challenge.

\section{First Cycle: Post-Revolution and State-Centralization 1959-1966}

Between 1959 and 1962, Castro implemented various changes like the nationalization of U.S. businesses and agrarian land reform, which further solidified Cuba's economic break from the U.S. Castro seized hundreds of millions of dollars of capital from American businesses, filling the government's coffers and delivering tremendous potential for state production. As a way of determining the value of the expropriation and providing a legal channel to regain losses, the United States government established the Cuban Claims

\footnotetext{
${ }^{43}$ Mesa-Lago, Carmelo, Jorge Pérez-López. Cuba Under Raúl Castro: Assessing the Reforms, 1st Edition. Lynne Rienner Publishers, 06/2013: 2-3.
} 
Program in 1964 as an extension of the Foreign Claims Settlement Commission, and the Cuban Claims Program met between 1966 and 1972:

During that time, it received 8,816 claims: 1,146 by U.S. corporations and 7,670 by individual U.S. citizens. It certified 5,911 of these claims, with an aggregate amount of $\$ 1.8$ billion; denied 1,195 claims, with an aggregate amount of $\$ 1.5$ billion; and dismissed without consideration (or saw withdrawn) 1,710 other claims. ${ }^{44}$

This $\$ 1.8$ billion dollars of certified claims does not include interest and represents a fair market value estimate of the amount of seized property claimed by the Cuban government. These claims still remain active today although many of the companies no longer exist or have been absorbed into different corporations. The vast accumulation of wealth provided a major advantage to a government that desired to transition to a state-planning model.

In 1962, in response to Cuba's move to establish far-reaching trade arrangements with the Soviet bloc and its attempt to place Soviet missiles on the island, President Kennedy declared an executive directive that forbade U.S. commerce with Cuba and prohibited Cuban imports. These restrictions placed extensive pressure on the Cuban economy, and Castro quickly turned to the Soviet Union for aid. As the United States retreated from Cuba, the Soviet Union increased its presence. Besides the $\$ 1.8$ billion in expropriations, the Cuban government also received a substantial post-revolution advantage through Soviet credits, approximately $\$ 600$ million during the period of $1959-1963 .{ }^{45}$ Fifty percent of these credits helped finance economic development, while the other half was primarily focused on assisting Cuba with fulfilling its trade agreements with the Soviet Union. ${ }^{46}$ Over the same time period, other communist states offered another $\$ 157$ million in credits, expanding the development on the island. ${ }^{47}$ This source of financial credits serves as another component of

\footnotetext{
${ }^{44}$ Travieso-Diaz, Matias, "Some Legal and Practical Issues in the Resolution of Cuban Nationals' Expropriation Claims against Cuba," 16 J. Int'I L. 217 (2014).

${ }^{45}$ Walters, Robert S.. "Soviet Economic Aid to Cuba: 1959-1964". International Affairs (Royal Institute of International Affairs 1944-) 42.1 (1966): 81.

46 Ibid 81.

47 Ibid.
} 
Cuba's advantage as it embarked on establishing a new economic plan. Limiting the analysis of how these credits were utilized is the fact that "it is particularly difficult to evaluate the quality of Soviet aid to Cuba because of the paucity of materials on the subject."48 However, with that acknowledged, the available information still allows an informed judgment on governmental policies of the first cycle.

Cuba attempted to model its economic transition after Czechoslovakia, purchasing industrial equipment from the country. Che Guevara spent time in Eastern Europe studying its economic functions and manufacturing capabilities, and upon his return to Cuba, he set out an ambitious task of diversification and import-substitution industrialization. While plans were drawn, they were somewhat haphazard as reforms were instituted almost impulsively. ${ }^{49}$ The agrarian land reform and diversification of crops yielded unexpected downturns in the sugar industry. ${ }^{50}$ The idealism and raw ambition combined in an attempt to overhaul completely a capitalistic society into a state-controlled command economy. Interestingly enough, Castro disagreed with the communist model favoring a less intense socialist model. Nevertheless, whatever model the government found preferential did not endure.

The failure of the early transition of the economy was four-fold. First, the economic plan was rough, vague, and even non-existent in some areas. Second, the Czech model was a poor fit for Cuba, and following its manufacturing strategies did not promote the growth that the leaders expected. Third, the forced transition of the agricultural sector away from sugar and the rapid collectivization of land lacked stability and foresight, leading to significant declines in sugar production - the main export of the time. Fourth, the Cuban government's political differences with the United States and its desire for equitable wealth distribution created a mass exodus of managers and business leaders whose talent was needed during the

\footnotetext{
48 Ibid 83.

49 Mesa-Lago, Carmelo, Jorge Pérez-López. Cuba Under Raúl Castro: Assessing the Reforms, 1st Edition. Lynne Rienner Publishers, 06/2013: 6.

50 Ibid 6.
} 
transition. Although the fourth reason was not in the control of the Cuban government, the other three factors could have been prevented with better planning.

Moreover, the economic difficulties associated with the first cycle are deeply connected to the ideological and idealistic aspects of the revolution. Connecting these early years to the beginning of the Cuban revolution reveals a parallel that defines Fidel Castro during this time period. During Fidel Castro's time in Mexico as an exile from Cuba, he met Che Guevara, and together, the men plotted the overthrow of Batista. The plan consisted of sailing an 82-man company aboard a yacht the revolutionaries called Granma to Cuba and meeting up with local sympathizers to start the revolution. Batista's men killed 75 percent of the Granma rebels when they landed, decimating any chance Castro had of consolidating support. This idealism and their wholly unrealistic expectations illustrate the way in which these two revolutionary leaders thought. Luck alone and the loss of morale among Batista's army explains more about revolutionary victory than any other set of factors. The utter lack of a realistic, grounded understanding of economics helps to explain why their revolutionary economic transformations failed during the early 1960s.

After the unsuccessful first sub-cycle, a deliberative movement back to the monoculture export of sugar occurred. In 1961, sugar production totaled 6.7 million tons, but by 1964 , total production had decreased to 3.8 million tons, a $43 \%$ reduction in output. ${ }^{51}$ Realizing the policies were unsustainable, Fidel Castro famously proclaimed that Cuba would ramp up sugar production to 10 million tons by 1970 - a complete departure from the revolutionary goal of economic diversification. ${ }^{52}$ At the same time, the influential inner circle of Cuban politics diverged on strategy: one group favored a socialist transformation, and the other leaders, inclusive of Che, supported an idealistic communist state of affairs. Ultimately,

\footnotetext{
${ }^{51}$ Ritter, Arch. "Fidel's Phenomenal Economic Fiascoes: The Top Ten." The Cuban Economy. 17 Sept. 2010.

$52 \mathrm{lbid}$.
} 
in 1965, Che Guevara left Cuba to join in another revolution, leaving Fidel full power of economic decision-making.

\section{Second Cycle: Export-Oriented}

Now solely responsible for the economy, Castro introduced a new strategy of concentrating on sugar production. Unfortunately, the increase in production barely surpassed the production levels of 1961, and by 1970, Cuba only reached 8.5 million tons, 15 percent less than its forecasted goal and barely above the sugar-production levels of the 1950s. Moreover, it represents less than a 3 percent annual growth rate of sugar production during the 1960s. Therefore, it was actually a rather small feat of economic capability, particularly given that the regime focused all of its attention and energy on this goal. Although less impressive with further analysis, the policy change did expand sugar production 2.5 times from 1964-1970, illustrating, in part, the strength of export promotion.

In addition to the government's change in focus, this period also marshaled in a new method of economic planning. Castro articulated a new vision that incorporated Che Guevara's plan with his own personal philosophy, allowing him to consolidate power and control. ${ }^{53}$ Castro delivered a series of speeches in which called on Cubans to combine the institutional changes already in place with a revolutionary transformation of culture. He implored each Cuban man to change the way he thinks about himself and to become "a new man" that would volunteer his time and labor selflessly for the revolution. Fidel offered moral incentives to men who followed their leader unquestioningly and worked hard and sacrificed for the spirit of the revolution. Many Cubans rallied behind their charismatic leader. Seeing the potential for an egalitarian society, the government expropriated close to

\footnotetext{
53 Mesa-Lago, Carmelo, Jorge Pérez-López. Cuba Under Raúl Castro: Assessing the Reforms, 1st Edition. Lynne Rienner Publishers, 06/2013: 7.
} 
60,000 small enterprises and rid the society of family farm collectives, reorganizing the entire population around the public sector. ${ }^{54}$ In this idealism, Fidel developed a new economic policy of socialism and communism combined. It did not last long, however, as the economy quickly began to disintegrate.

\section{Third and Fourth Cycles: Soviet Dependency}

Adverse conditions that culminated in widespread economic crises pressured the Cuban government to seek additional help from the Soviet Union, fully shifting Cuba's relationship with the Soviet Union to one of dependency. This new - and more extensive relationship of dependency sustained for 20 more years. While the relationship prominently consisted of trade, geopolitical factors, and Cuban support of Soviet expansionism and communist rebellions around the world helped maintain the amicable nature of the deal. In 1972 the Soviet Union granted Cuba membership in the Council for Mutual Economic Assistance (CMEA). ${ }^{55}$ In this expanded trade role, the Soviet Union readily gave billions of dollars of aid to Cuba. As Figure 1 suggests below, Cuban trade with communist countries exploded after 1972, tripling its exports in 2 years. Such a drastic transformation shows the direct impact of Cuba's integration into the CMEA, and it suggests an improvement in economic production: "Economic growth recorded the highest average annual rate, particularly in 1971-1975, spurred by historically high world market prices for sugar."56 On the opposite side of this success, the Cuban government decided to invest heavily in its production in order to export sugar to other countries. By the time the capital had been spent, however, the market price of sugar plummeted, making the economic conditions worse for Cuba.

\footnotetext{
54 Ibid 8.

Ritter, Arch. "Fidel's Phenomenal Economic Fiascoes: The Top Ten." The Cuban Economy. 17 Sept. 2010.

${ }^{55}$ Mesa-Lago, Carmelo, Jorge Pérez-López. Cuba Under Raúl Castro: Assessing the Reforms, 1st Edition. Lynne Rienner Publishers, 06/2013: 9.

56 Ibid 10.
} 
Figure 1

\begin{tabular}{lrrrrrr} 
CUBAN FOREIGN TRADE & \multicolumn{7}{c}{ (in millions of U.S. dollars) } \\
& $\mathbf{1 9 5 7}$ & 1968 & 1970 & 1972 & 1974 & $1975^{*}$ \\
\cline { 2 - 8 } & 818 & 652 & 1,050 & 840 & 2,689 & 3,415 \\
\cline { 2 - 8 } $\begin{array}{l}\text { Total exports } \\
\begin{array}{l}\text { Communist } \\
\quad \text { countries }\end{array}\end{array}$ & 42 & 480 & 778 & 451 & 1,536 & 2,415 \\
Non-Communist & 776 & 172 & 272 & 389 & 1,153 & 1,000 \\
\cline { 2 - 8 } & 895 & 1,103 & 1,311 & 1,297 & 2,693 & 3,805 \\
\hline Total imports & 2 & 875 & 905 & 997 & 1,629 & 2,105 \\
Communist & 893 & 228 & 406 & 300 & 1,064 & 1,700 \\
$\quad$ countries & & & & & &
\end{tabular}

Discrepancies in the economic data of Cuba's external sector during this time period provide the need for verification of statistics. Figure 1 comes from a sub-committee hearing of the United States Congress. The table has been combined with a table from Cuba's National Office of Statistics in order to determine validity (See Figure 2). The years 1950, 1955, 1960, 1965, 1970, and 1975 are taken from the Annual Report of the External Sector of the Cuban Economy, which is published by the Cuban National Office of Statistics. The value of the imports and exports are in millions of pesos. The years 1957, 1968, 1970, 1972, 1974, and $1975^{* *}$ are from Figure 1, which comes from a United States congressional subcommittee, and the values are in millions of dollars. When amalgamating the tables, the 1970 values were identical, leading to a conclusion that the measurement of pesos accurately reflects U.S. dollars. At the time, the convertible peso did not exist, and the exchange rate between local pesos and convertible pesos fluctuated; therefore, without comparison, that data requires extra scrutiny. The exact match shows that there is not a problem with that year and most likely can be generalized to the whole. Unfortunately, the 1975 preliminary exports and imports do not align with the data from the Office of National Statistics. Since the

\footnotetext{
${ }^{57}$ Fagen, Richard R.. "Cuba and the Soviet Union". The Wilson Quarterly (1976-) 2.1 (1978): 75. [citing "United Staes-Cuba Trade Promotion." Hearing before the Subcommittee on International Trade and Commerce of the House Committee on International Relations. July 22, 1976, Washington, D.C., Government Printing Office, 1976, p. 37.].
} 
subcommittee report occurred in 1976, this difference might have been corrected following that meeting. Nonetheless, this discrepancy serves as an anecdotal evidence of the difficulties that come with an economic analysis of this time period.

\section{Figure 2}

\begin{tabular}{|r|r|l|r|}
\hline \multicolumn{5}{|c|}{ Cuban Foreign Trade (In Millions of Pesos/Dollars) } \\
\hline Years & Exports & Imports & Net Exports \\
\hline 1950 & 642 & 515 & 127 \\
\hline 1955 & 594 & 575 & 19 \\
\hline 1957 & 818 & 895 & -77 \\
\hline 1960 & 608 & 580 & 28 \\
\hline 1965 & 691 & 866 & -175 \\
\hline 1968 & 652 & 1103 & -451 \\
\hline $1970 *$ & 1050 & 1311 & -261 \\
\hline 1972 & 840 & 1297 & -457 \\
\hline 1974 & 2689 & 2693 & -4 \\
\hline 1975 & 2952 & 3113 & -161 \\
\hline $1975^{* *}$ & 3415 & 3805 & -390 \\
\hline
\end{tabular}

The CMEA helped Cuba escape its trade deficiency through augmented prices and larger export deals. These major advancements in the Cuban economy posit the question: Why did Cuba not receive admission to the CMEA prior to 1972? The Soviet Union had considered this possibility back in 1960 at the very beginning of Castro's anti-American rhetoric and policies. Among the communiques sent out by the Soviet Union during 1960 was a report to Czechoslovakia about the upcoming visit by Che Guevara. ${ }^{59}$ In the report, the Soviet Union had a direct recommendation to Czechoslovakia if Che Guevara asked about Cuba's prospects of joining CMEA:

\footnotetext{
58 Ibid 37.

"Sector Externo." Anuario Estadístico De Cuba (2014): Oficina Nacional De Estadística e Información. 2015.

*1970 imports and exports are identical between both sources, yet they claim different currencies.

**1975 imports and estimates are preliminary from the subcommittee hearing (3415 and 3805).

59 "Documents Regarding Impending Visit to Czechoslovakia of Ernesto "Che" Guevara, president of the Cuban National Bank," October, 1960, History and Public Policy Program Digital Archive, National Archives, Prague, Czech Republic.
} 
A decision can be made only after consultations with all member countries of the CMEA; Inform Mr. Guevara about the conditions for membership in the CMEA, which are based on an accepted Statute of the CMEA. Emphasize that based on this accepted Statute of the CMEA, only European countries may become members of the Council, and that other countries can participate in the work of the Council for Mutual Economic Assistance on selected issues. Inform Mr. Guevara about the main objectives of the CMEA, namely coordination of plans for the next 20 years. $^{60}$

This report reflects the Soviet mindset toward the CMEA in 1960, and while its official stance was to restrict the CMEA to European states, the Soviet Union still advocated for a broad partnership with Cuba and asked the Czechoslovak trade representatives to assist in the financing of Cuban development. However, Che, in fact, did not specifically request membership in the CMEA because at that time the Cuban government still hoped to be able to broadly diversify its trade relationships beyond the Soviet bloc. Moreover, a few political disagreements, including the Soviet decision to remove the missiles from Cuba without informing Fidel Castro, prolonged the time period before the Soviet Union finally admitted Cuba into the CMEA. Without these political differences, the Cuba government might have prospered much earlier, and speculatively, the economy might have been in a better position to withstand the collapse of the Soviet Union in the early 1990s.

The trade benefits from the CMEA were substantial; however, Soviet aid outpaced those benefits. Figure 3 compares the aid given to Cuba to the aid received by Vietnam. This significant difference underscores the high value of Cuba's geopolitical location and its degree of dependency. A closer observation reveals that the Vietnamese invested their aid in rapidly expanding sectors that produced prosperity while the Cubans failed to invest at all in sectors that produced growth. In fact, economists have confirmed that much of the Soviet aid was never invested in the economy at all. Certainly it was not invested in an effort to enhance economic self-sufficiency.

${ }^{60} \mathrm{lbid}$ 9-10. 
Figure 3

\section{Soviet Aid (million U.S. dollars)}

$\begin{array}{lrlllll}\text { Year } & \underline{\mathbf{1 9 8 0}} & \underline{\mathbf{1 9 8 2}} & \underline{\mathbf{1 9 8 4}} & \underline{\mathbf{1 9 8 6}} & \underline{\mathbf{1 9 8 8}} & \underline{\mathbf{1 9 9 0}} \\ \text { Cuba } & 3,243 & 4,340 & 5,153 & 3,280 & 3,270 & 3,955 \\ \text { Vietnam } & 935 & 1,000 & 1,040 & 1,325 & 1,365 & 585\end{array}$

While difficult to quantify, the Soviet subsidies amounted to approximately $\$ 25$ billion in aid between 1965 and 1980. The principle methods for these subsidies occurred through the exchange of oil, nickel and sugar. In 1975 the Soviet bloc purchased sugar from Cuba at $\$ 0.50$ per pound, while the world market price of sugar hovered at around $\$ 0.05$ per pound. At its peak, Cuba produced almost 10 million tons of sugar annually, which would equate to a subsidy of almost $\$ 9$ billion. This drastic overpayment for sugar describes one method the Soviet Union subsidized the Castro government. Real issues developed from the rich amounts of aid that the Soviet Union gave to Cuba. First, the cost of production became distorted. Since the Soviet Union paid a premium above the world sugar price, Cuba did not have to compete with the price and quality of the rest of the world, leading to lags in production. Second, the Soviet Union sold oil to the Cubans at well below the world price. The re-exporting of oil on the world market amounted to one of the island's top hardcurrency earners. Cuba became accustomed to re-exporting oil that it did not consume. ${ }^{62}$ This reliance on re-exportation created a high degree of dependency because the profit depended on aid.

\footnotetext{
61 Yamaoka, Kanako. Comparison of Two Remaining Socialist Countries-Cuba and Vietnam: Possibility of Economic Reform in a Socialist Society and Its Possible Impact. Issue brief no. 07-15. Cambridge, MA: Program on U.S.-Japan Relations, Harvard University, 2007. [citing CIA Handbook].

62 Mesa-Lago, Carmelo, Jorge Pérez-López. Cuba Under Raúl Castro: Assessing the Reforms, 1st Edition. Lynne Rienner Publishers, 06/2013: 10.
} 


\section{Fifth and Sixth Cycles: Special Period in Time of Peace and Restructuring}

After the collapse of the Soviet Union in 1991 and the tightening of the U.S. embargo in 1996, Cuba became independent of influence with the exception of the negative pressure from the embargo. The economies of the European Union and Latin America distanced themselves from the Cuban crisis, and the island faced extreme economic perils. Characterized as the Special Period in Time of Peace, poverty rates skyrocketed, and economic production virtually stopped. For the first time in its history, Cuba had finally achieved independence, and its economy was rapidly collapsing. Castro worked to motivate Cubans to work without wage in order to fulfill the ideals of the revolution, and he labeled these years as the "special period," which he insisted would, through hard work, lead to economic prosperity. He revitalized his call to each Cuban to become the "new man" and offered moral incentives in lieu of salaries.

While the Spanish, American and Soviet periods have been addressed, the past 25 years also support the idea that the Cubans turned to other countries to make the investments. Castro actively sought out international partners during the Special Period, and he leveraged his shared socialist virtues with newly transitioning Latin American states. This connection led to a lucrative partnership with Venezuela. Through a creative deal, Cuba exchanged doctors for oil and then took a hefty cut of the doctors' wages to fund the government. The government opened its poorly performing industries to foreign investment and attracted Canadian's Sherritt Corporation to modernize its nickel mining industry.

\section{Modern-day Reforms}


Since gaining office in 2006 Raul Castro has initiated a new phase. Accelerating privatization, that began out of necessity in the 1990s, revising foreign investment laws, and expanding tourism has strengthened the economy slightly. His announcement that he plans to step down in 2018 has stimulated more reforms, which has helped to build domestic confidence in the government. Cuba's long pre-revolutionary tradition of being highly entrepreneurial and productive, economists hope, will contribute to the current effort to recover. One of Cuba's most valuable sources of hard currency is its export of human capital. The government has for years sent abroad doctors, coaches and trainers, and other professionals to serve the needs of other countries. The government is paid for these services, and it pays the professionals the going wage in Cuba. Another significant source of hard currency in Cuba are remittances sent to Cuba from Cubans and Cuban-Americans living in the United States. The third most profitable sector is tourism. All three of these economic sectors depend on an international flow of goods and services. The government continues to struggle to attract investment and draw on the global supply of goods and services, while avoiding the creation of another highly dependent economic relationship. This historical context provides the framework for assessing the Cuban economic model and the necessary economic changes.

The bewildering issue that continues to plague Cuba is its inefficiency and lack of production. After extensive analyses of the Cuba economy, economists have found that 3 percent of government corporations accounted for 75 percent of the state's profit. This revelation remained shrouded by the dual currency system, which allowed state enterprises to veil their profit margins and losses. By 2016, the government hoped to transition 2 million people to non-state sectors, roughly 40 percent of the labor force. ${ }^{63}$ However, in 2014, only

\footnotetext{
${ }^{63}$ Feinberg, Richard, and Ted Piccone. Cuba's Economic Change in Comparative Perspective. Latin America Initiative Foreign Policy at Brookings, 2014: 3.
} 
600,000 workers had been restructured to the private sector. Unfortunately, the movement of workers to entrepreneurship did not yield the expected results: "Whereas the global average is for one self-employed to employ five others, the situation in Cuba is completely the opposite (only one out of five creating one additional job). ${ }^{964}$ If Cuba had followed the global average, there would already be 2.5 million people working in private enterprises; however, the stifling taxes, licensing fees, and mistrust of the government have prevented this growth. In a way, this reflects Cuba's poor social capital as it is unable to create new jobs at the same rate as other comparable countries.

Besides simply transitioning workers from the state sector, the government must also address the inefficiencies and corruption found in state enterprises; for example, in 2008, the Ministry of Labor and Social Security through an in-depth survey found that almost 50 percent of state employees were arriving to work late. ${ }^{65}$ The deeply rooted and systemic problem of inefficiency highlights how badly the economy is performing. In 2009 the government finally abandoned the lunch it provided to more than 3.5 million workers and replaced it with a 15 pesos per week raise in wage, approximately $\$ 0.60 .{ }^{66}$ While a small raise relative to the U.S. dollar, the increase was rather significant since most Cuban workers received less than 500 pesos a month. The shift also foreshadowed a movement by the government to eliminate underperforming public services in favor of public sector growth. Although reports might not publically suggest the support of private entrepreneurship and many of the laws and taxes hamper private economic growth and employment, the fundamental shift expanded business opportunities for local restaurants that do not target tourists.

\footnotetext{
${ }^{64}$ Bye, Vegard. "Political Implications of Recent Economic Reform Trends in Cuba: The 2014 Status." Association for the Study of the Cuban Economy 24 (2014): 42.

${ }^{65}$ Mesa-Lago, Carmelo, Jorge Pérez-López. Cuba Under Raúl Castro: Assessing the Reforms, 1st Edition. Lynne Rienner Publishers, 06/2013: 174.

66 "The Demise of the Free Lunch." The Economist. The Economist Newspaper, 10 Oct. 2009. Web. 03 Mar. 2016.
} 


\section{Prospects of Foreign Investment}

Since the collapse of the Soviet Union, Cuba has made various attempts to garner foreign direct investment in order to replace its largest trading partner, but for every promotional action it has made, the government has regressed and made investments riskier. The government tends to redo its foreign investment policy every 5-10 years, and it has exercised its prerogative in canceling partnerships after the initial contractual period finishes. For example, in 2002, Cuba had over 400 joint ventures with foreign entities, but by 2008, it retrenched and canceled contracts with half of the foreign corporations, citing a variety of reasons for the cancellations. ${ }^{67}$ In addition, when state enterprises feel threatened by the competition of foreign investment, they often exert influence over other enterprises, ultimately causing the joint venture's electricity rates to spike, rent to be increased, and visas to be denied. ${ }^{68}$ If these issues are not enough to discourage investment, a comparison to the rest of South America illuminates other reasons to invest elsewhere. Cuba's 2014 Foreign Investment Act requires a special approval process, which has been previously explained, yet none of the 14 Latin American countries surveyed by Investing Across Borders in 2010 have special hurdles for foreign investment. ${ }^{69}$ Additionally, these countries fully opened most of their economic sectors to foreign investment without limiting the equity arrangement of foreign entities; however, a few sectors like electricity, banking, and telecommunications were noted as areas that the governments are more likely to protect. ${ }^{70}$ This contrasts negatively with the rules and limitations that Cuba places on foreign investment. Such

\footnotetext{
${ }^{67}$ Feinberg, Richard E. The New Cuban Economy: What Roles for Foreign Investment? Washington, DC: Brookings Institution, 2012: 22.

68 Ibid 22.

69 Ibid 16.

70 Ibid 16.
} 
actions limit profit and diminish the incentives in investing. While the media has recently given great press coverage of the possibilities for American and other international corporations in Cuba, the articles fail to give an accurate picture of the volatile and secretive climate that shrouds foreign investments. A relevant conclusion made by the Investing Across Borders 2010 study was that "Easily accessible and reliable information and efficient and predictable actions by public institutions help create a business environment conducive to investment." 71 This recommendation and conclusion helps recognize the need for strong social capital to attract foreign direct investment. A country that lacks international trust and that operates under a cloud of secrecy tends to foster an environment that is hostile to investment. As Cuba looks to expand the foreign investment on the island, it must work to compete with countries that offer investment relationships based on trust, adding another difficult impediment of economic growth.

In The New Economy: What Roles for Foreign Investment?, Richard Feinberg attempts to assess the Cuban climate for foreign direct investment in 2012. First, Feinberg divides the past 50 years into 5 distinct periods of the government's policies toward foreign direct investment: 1) revolutionary period of expropriation and nationalism; 2) the postSoviet phase of attracting FDI and liberalizing the economy; 3) a movement to return to a closed system through the cancellation of contracts; 4) a decision to create a "New Socialism" by focusing on attracting socialist countries to invest like Venezuela, China, and Brazil; and 5) an ambivalent period that is characterized by a transition away from historic models toward sweeping economic reforms. ${ }^{72}$ Categorizing these phases show a progression and regression of policies - continual shifts and counterbalances to change. The government's decisions reflect its desperation to maintain the revolutionary spirit of the

\footnotetext{
${ }^{71} \mathrm{lbid} 16$.

72 Ibid 5.
} 
country and its pragmatism in times of need. The major questions that arise relate to what is next. Does the ambivalence change to complete acceptance of trade and liberalization? If so, would a reform of openness last, or would a period of retrenchment follow? Although future predictions of policy decisions requires some guesswork, the historic precedent and current attitude toward foreign investment allows for a consideration of what will occur next, acknowledging that a political transition might alter any current framework for assessment. In the face of this uncertainty, however, the Cuban economy is still severely underperforming: agriculture production is below 1988 levels, and national savings and investment only account for 10 percent of GDP, lagging the Latin American average by 10 percent. $^{73}$

Feinberg's case study of 7 joint ventures in Cuba presents some of the advantages and disadvantages of foreign investment in Cuba. ${ }^{74}$ While the potential industries for investment are not surprising, the anecdotal examples reinforce common presuppositions. Tobacco, nickel, gas, tourism and agriculture are all areas that Cuba sought to improve its production and quality. Beginning in 1995, the government felt pressure to open up these areas of its economies in order to bring hard currency to the island. Minimizing imports and maximizing exports appears to be a consistent theme in Feinberg's paper, and it highlights the government's scrupulous approach to attracting partners who have a net positive impact on Cuba's hard currency reserves. Almost every survey of foreign investments in Cuba critically evaluates the difficulties that are associated with the process. As Feinberg notes in the case studies he presents, the Cuban government consistently make business more difficult and uncertain, and they keep a sizeable portion of the profits through currency conversions and their joint stake. ${ }^{75}$ While businessmen are optimistic about a complete transition in Cuba and

\footnotetext{
73 Ibid 8.

74 "The Demise of the Free Lunch." The Economist. The Economist Newspaper, 10 Oct. 2009. Web. 03 Mar. 2016.

${ }^{75}$ Feinberg, Richard E. The New Cuban Economy: What Roles for Foreign Investment? Washington, DC: Brookings Institution, 2012: 14.
} 
the opening up for investment, the past should not be overlooked, and while the more intense example is the expropriation that occurred in the 1960s, Cuba still institutes policies that forces companies to give high percentages of their earnings to the government. One example of how Cuba accesses these earnings is through its method of collecting and then converting wages. The government receives payment of its workers in convertible pesos, but it pays them in local currency, which accounts for a 90 percent tax on labor. ${ }^{76}$ A study in 2000 by the United Nations found that the costs of Cuban workers in free trade zones were on average $\$ 1.75$ an hour compared to the cheaper rate of workers in the Dominican Republic of $\$ 0.94$ per hour. ${ }^{77}$ This comparison reveals that foreign corporations paid an 85 percent premium for Cuban workers in contrast to workers in the Dominican Republic. This sizeable difference adds to policy changes that Cuba must endure to become a competitive market internationally.

While expediency and efficiency have been addressed, in 2012, the Cuban government involved a multi-step process for foreign direct investment, which led to scrutiny by multiple government organizations. For the most part, it appears to be in place today; however, each business seems to have a different timeline in approval. First, the corporation must apply for a joint venture with a particular Cuban government agency, and second, the company must address approval from Ministry of International Commerce and Foreign Investment. ${ }^{78}$ This step will lead to consultation of the banking and finance branches of the government; in addition, a recommendation will then be made to the Executive Committee of the Council of Ministers. Finally, upon acceptance, the proposal will be put into action, but the timeline appears unclear. Although the law requires a 60-day response, the process can easily be prolonged because of the various obstacles in the formal procedures. Fortunately,

\footnotetext{
76 Ibid 14.

77 Ibid 18.

78 Ibid 13.
} 
the new law has improved the transparency and possibility of acceptance by including over 150 potential joint ventures. The new investment law technically allows for a completely private venture, but that has not yet occurred since its passage, reflective of the central government's desire to influence and control all economic decisions.

Cuba's past 25 years have been characterized by economic crises and difficulties. However, as the Cuban government looks to transform the economy, it must be careful not to sacrifice the successes of the revolution along the way - chiefly the equity and socioeconomic improvements. As Vietnam has been seen as a model, examining the impact of the economic transformation on its society has a clear relation to Cuba's future. A key characteristic of the Vietnamese transition related to its shift in policies from an equitable socialism to a market-driven liberalization, emblematic of this change was the reduction of the tariffs, which opened Vietnam up for investment: "By the mid-1980s tariff rates began to steadily fall, with the average at 85 percent, reaching 6 percent in 2002 and only 2 percent [in 2014]."79

To be clear, Vietnam followed a path of development that emphasized economic growth over social equity, contrary to the Cuban government's stance on growth except emergent crises. ${ }^{80}$ Thus, as Cuba looks to the Vietnamese model, it should forecast the effect of some of the policy initiatives on social equity as the inequity in Vietnam skyrocketed after reforms. Concurrently, the agricultural production tripled in a period of two decades and the GDP increased 4 times over its 1980 value. ${ }^{81}$ Thus, the advantages of rapid economic growth must be weighed against the reality that if 4-5 percent growth rates are to occur as Cuban

\footnotetext{
${ }^{79}$ Feinberg, Richard, and Ted Piccone. Cuba's Economic Change in Comparative Perspective. Latin America Initiative Foreign Policy at Brookings, 2014: 73.

${ }^{80}$ Yamaoka, Kanako. Comparison of Two Remaining Socialist Countries-Cuba and Vietnam: Possibility of Economic Reform in a Socialist Society and Its Possible Impact. Issue brief no. 07-15. Cambridge, MA: Program on U.S.-Japan Relations, Harvard University, 2007.

${ }^{81}$ Yamaoka, Kanako. Comparison of Two Remaining Socialist Countries-Cuba and Vietnam: Possiblitity of Economic Reform in a Socialist Society and Its Possible Impact. Issue brief no. 07-15. Cambridge,MA: Program on U.S.-Japan Relations, Harvard University, 2007.
} 
economists project, the social equality of the state will most likely be an afterthought. Omar Everleny's perspective on Vietnam as a model for Cuba does not completely agree with this critique: "Vietnam has been able to introduce the market into its model and has become an economy with high rates of growth, improving the welfare of its citizens, and becoming a leader in world exports." ${ }^{\prime 2}$ This analysis provides that the economic growth will be widely dispersed, leading to an improvement in the standard of living for most citizens. However, current trends suggest that this might not be the case. Newspapers already cover the rise of inequality in Cuba, connecting it to President Obama's increase in remittances allowed annually and the Cuban government's easement of restrictions against private enterprise. ${ }^{83}$ As Cubans receive cash inflows from relatives in the United States, they have the opportunity to make strategic investments that are helping them become wealthy elites, and as this is happening, new tiers of classes are beginning to emerge. Some level of equality may have to be sacrificed in order to attain a higher standard of living for all citizens.

\section{Conclusion}

While Cuba faces crippling obstacles and some serious disadvantages, including a lack of trust, a poor national infrastructure, an abysmal technological grid, and a very low level of worker productivity, it has the ability to reform both its infrastructure and technology in the coming years, and as it opens its shores to the international community and transitions its leadership, some of these issues will diminish in their intensity. In this context, a comprehensive study of the functions of the Cuban economy is critical as Cuba continues to develop and seek international investment. However, from this study, a few observations can

\footnotetext{
82 Mesa-Lago, Carmelo, Jorge Pérez-López. Cuba Under Raúl Castro: Assessing the Reforms, 1st Edition. Lynne Rienner Publishers, 06/2013: 174.

${ }^{83}$ Archibold, Randal C. "Inequality Becomes More Visible in Cuba as the Economy Shifts." New York Times. 24 Feb. 2015.
} 
be made about the next steps of Cuba's economic transition. A key comparative advantage Cuba possesses is its highly trained and educated population, combined with its investments in healthcare. Its human capital will promote investments by firms that need specialized labor, and as such, Cuba should continue to invest in higher education, while also working to attract these firms to the island. The government must continue its course to attract investment by acting as a better steward to corporations who apply for contracts. By eliminating the dual currency system, the government will reduce the tax it takes from wages, which will lead to a reduction in the cost of labor, making Cuba more competitive internationally. State-owned enterprises need to do a better job of welcoming foreign entities rather than discriminating against them, reducing the amount of unequal treatment. Moreover, the barriers should be eliminated in sectors the government does not have a vested interest in protecting. An example where high tariffs might be beneficial is agriculture, but at the same time, the government should offer tax incentives to local citizens who make the land more productive and profitable. When the embargo ends, Cuba should be wary of the United States influence, maintaining safeguards against dependency. While this might sacrifice growth, it will protect the country against a new wave of economic dependency, and through a thoughtful economic plan, Cuba will be in a better position to integrate into the world market. Social capital matters, and goodwill has a high intrinsic economic value. The next political leaders should be mindful of how their actions will be perceived by the international community because it will directly affect the levels of international investment. Another way of promoting better relations would be to switch dispute resolution to an international arbitrator for the next ten years in order to foster more international trust. Cuba must also manage its debt and find ways to settle old claims in order to integrate successfully into the global economy. If Vietnam is the model that the government follows, the equity and gains of the revolution should be protected by not just focusing on growth. Cuba's future is uncertain 
both economically and politically; therefore, the decisions made by Cuban leaders today will have a major impact on the country that Cuba becomes.

\section{Anecdote}

During my time in Cuba, I spent a week on a cross-country tour of the island, and my academic cohort had a native Cuban guide that provided us with ample information about the politics, history, culture, and economy. While much of the tour seemed to be regurgitated facts, stories, and jokes, one of my exchanges with the guide captured what I believe to be an overwhelming sentiment on the island. The highways were in ill-repair, and while many developing nations have poorly constructed national infrastructures for transportation, Cuba's neglect appeared to have gone on for over fifty years. When I probed the tour guide about how the government would finance the project of rebuilding, the answer was quick, seemingly unrehearsed: "Someone else will pay for it. We need another country to build these highways and fix our buildings. Cuba is broke. The government has no money to do it." Cuba's foreign debt echoes this statement, but the tour guide's admission points to a more glaring critique on the Cuban society. For five hundred years, Cuba has been accustomed to receiving vast injections of foreign capital and investment. The revolution promised independence, but it did not deliver. 


\section{Works Cited}

Archibold, Randal C. "Inequality Becomes More Visible in Cuba as the Economy Shifts." New York Times. 24 Feb. 2015.

Baer, Werner. "Import Substitution and Industrialization in Latin America: Experiences and Interpretations". Latin American Research Review 7.1 (1972): 95-122.

Baranson, Jack. Automotive Industries in Developing Countries. (Baltimore 1969).

Best, Lloyd, and Kari Levitt. Essays on the Theory of Plantation Economy: A Historical and Institutional Approach to Caribbean Economic Development. Kingston, Jamaica: U of West Indies, 2009.

Betancourt, Roger. "Cuba 2014: A Different Perspective on Cuba's "Structural” Reforms. Association for the Study of the Cuban Economy 24 (2014).

Bresnan, John. From Dominoes to Dynamos: The Transformation of Southeast Asia. New York: Council on Foreign Relations Press, 1994.

Brundenius, Claes, and Pérez R. Torres. No More Free Lunch: Reflections on the Cuban Economic Reform Process and Challenges for Transformation. 2013.

Bruton, Henry J.. “A Reconsideration of Import Substitution”. Journal of Economic Literature 36.2 (1998): 903-936.

Bye, Vegard. "Political Implications of Recent Economic Reform Trends in Cuba: The 2014 Status." Association for the Study of the Cuban Economy 24 (2014).

Caves, Richard E.. "Multinational Firms, Competition, and Productivity in Host-country Markets”.Economica 41.162 (1974).

"The Demise of the Free Lunch." The Economist. The Economist Newspaper, 10 Oct. 2009. Web. 03 Mar. 2016. 
"Documents Regarding Impending Visit to Czechoslovakia of Ernesto "Che" Guevara, President of the Cuban National Bank," October, 1960, History and Public Policy Program Digital Archive, National Archives, Prague, Czech Republic.

Fagen, Richard R.. “Cuba and the Soviet Union”. The Wilson Quarterly (1976-) 2.1 (1978).

Feinberg, Richard E. The New Cuban Economy: What Roles for Foreign

Investment? Washington, DC: Brookings Institution, 2012.

Feinberg, Richard. Open for Business: The New Cuban Economy. S.1.: Brookings Institution $\operatorname{Pr}, 2016$.

Feinberg, Richard, and Ted Piccone. Cuba's Economic Change in Comparative Perspective. Latin America Initiative Foreign Policy at Brookings, 2014: 73.

Frey, Marc, Ronald W. Pruessen, and Tai Yong. Tan. The Transformation of Southeast Asia: International Perspectives on Decolonization. Armonk, N.Y.: M.E. Sharpe, 2003.

Froot, Kenneth. Foreign Direct Investment. Chicago: U of Chicago, 1993.

Fukuyama, Francis. The End of History and the Last Man. New York: Free, 1992.

Fukuyama, Francis. Trust: The Social Virtues and the Creation of Prosperity. New York:

Free, 1995.

Given, Norman. "The Plantation Economy in the Age of Globalization." Rpt. in Essays on the Theory of Plantation Economy. U of the West Indies, 2010.

Hirschman, Albert O. 1968. The Political Economy of Import-Substituting Industrialization in Latin America. Quarterly Journal of Economics 82, 1: 1-32.

Jomo K. S. Southeast Asia's Industrialization: Industrial Policy, Capabilities, and Sustainability. Houndmills, Basingstoke, Hampshire: Palgrave, 2001.

Krueger, Anne O. "Trade Policy as an Input to Development." The American Economic Review, Vol. 70, No. 2, (May 1980), pp. 288-292.

Law No. 118 Foreign Investment Act. National People's Power Assembly. Mar. 29, 2014. 
Leogrande, William M., and Julie M. Thomas. "Cuba's Quest for Economic Independence”. Journal of Latin American Studies 34.2 (2002): 325-363.

Le, Quoc-Phuong. “Evaluating Vietnam's Changing Comparative Advantage Patterns". ASEAN Economic Bulletin 27.2 (2010): 221-230.

Machikita, Tomohiro, and Yasushi Ueki. "Measuring and Explaining Innovative Capability: Evidence from Southeast Asia." Asian Economic Policy Review 10.1 (2015).

Mesa-Lago, Carmelo, Jorge Pérez-López. Cuba Under Raúl Castro: Assessing the Reforms, 1st Edition. Lynne Rienner Publishers, 06/2013.

Ray, Edward John. "Foreign Direct Investment in Manufacturing”. Journal of Political Economy 85.2 (1977).

Ritter, Arch. "Fidel's Phenomenal Economic Fiascoes: The Top Ten." The Cuban Economy. 17 Sept. 2010.

Ritter, Archibald R., Ted Henken. Entrepreneurial Cuba: The Changing Policy Landscape. First Forum Press, 11/2014.

"Sector Externo." Anuario Estadístico De Cuba (2014): Oficina Nacional De Estadística e Información. 2015.

Tomz, Michael, and Mark L. J. Wright. "Sovereign Theft: Theory and Evidence about Sovereign Default and Expropriation." 2008.

Thomas, Linus J.. "Neoclassical Development Theory and the Prebisch Doctrine: A Synthesis". The American Economist 38.1 (1994): 75-81.

Travieso-Diaz, Matias, "Some Legal and Practical Issues in the Resolution of Cuban Nationals' Expropriation Claims against Cuba,” 16 J. Int'1 L. 217 (2014).

Walters, Robert S.. "Soviet Economic Aid to Cuba: 1959-1964”. International Affairs (Royal Institute of International Affairs 1944-) 42.1 (1966): 74-86. 
Widodo, Tri. "Dynamic Comparative Advantages in the ASEAN+3". Journal of Economic Integration 24.3 (2009): 505-529.

Yamaoka, Kanako. Comparison of Two Remaining Socialist Countries-Cuba and Vietnam: Possiblitity of Economic Reform in a Socialist Society and Its Possible Impact. Issue brief no. 07-15. Cambridge,MA: Program on U.S.-Japan Relations, Harvard University, 2007.

Yamaoka, Kanako. The Feasibility of Cuban Market Economy: A Comparison with Vietnam. Issue brief no. 189. Chiba-Shi Chia Japan: Institute of Developing Economies. 